\title{
Efficient removal of hospital pathogens from hard surfaces by a combined use of bacteriophages and probiotics: potential as sanitizing agents [Corrigendum]
}

\author{
D’Accolti M, Soffritti I, Piffanelli M, Bisi M, Mazzacane \\ S, Caselli E. Infect Drug Resist. 2018;11:1015-1026.
}

Page 1018, Bacteriophages section, the text "All bacteriophages used in this study were obtained from Eliava Institute (Staphylococcal phage and Pyophage; GA, USA)" should read "All bacteriophages used in this study were obtained from Eliava Institute (Staphylococcal phage and Pyophage; Tbilisi, Georgia)".

resistance and the mechanisms of resistance development and diffusion in both hospitals and the community. The manuscript management system is completely online and includes a very quick and fair peer-review system, which is all easy to use. Visit http://www.dovepress.com/testimonials. php to read real quotes from published authors. 